\title{
Supporting the Development of Procedures for Communications During Volcanic Emergencies: Lessons Learnt from the Canary Islands (Spain) and Etna and Stromboli (Italy)
}

\author{
M.C. Solana, S. Calvari, C.R.J. Kilburn, H. Gutierrez, \\ D. Chester and A. Duncan
}

\begin{abstract}
Volcanic crises are complex and especially challenging to manage. Volcanic unrest is characterised by uncertainty about whether an eruption will or will not take place, as well as its possible location, size and evolution. Planning is further complicated by the range of potential hazards and the variety of disciplines involved in forecasting and responding to volcanic emergencies. Effective management is favoured at frequently active volcanoes, owing to the experience gained through the repeated 'testing' of systems of communication. Even when plans have not been officially put in place, the groups involved tend to have an understanding of their roles and responsibilities and those of others. Such experience is rarely available at volcanoes that have been quiescent for several generations. Emergency responses are less effective, not only because of uncertainties about the volcanic system itself, but also because scientists, crisis directors, managers and the public are inexperienced in volcanic unrest. In such situations, tensions and misunderstandings result in poor communication and have the potential to affect decision making
\end{abstract}

M.C. Solana $(\bowtie)$

School of Earth and Environmental Sciences, University of Portsmouth, Portsmouth PO1 2UP, UK e-mail: Carmen.solana@port.ac.uk

M.C. Solana

Instituto Volcanológico de Canarias (INVOLCAN), Antiguo Hotel Taoro, Parque Taoro, 22, 38400

Puerto de La Cruz, Tenerife, Spain

S. Calvari

INGV, Piazza Roma 2, 95125 Catania, Italy

C.R.J. Kilburn

UCL Hazard Centre, Department of Earth Sciences, University College London, Gower Street, London WC1E 6BT, UK

\section{H. Gutierrez}

Servicio de Protección Civil Y Atención de Emergencias, Gobierno de Canarias, Carretera de La Esperanza Km 0,8 Edf. Ceplam, 38071 Tenerife, Spain

D. Chester

Department of Geography and Environmental Science, Liverpool Hope University, Hope Park, Liverpool L16 9JD, UK

D. Chester · A. Duncan Department of Geography and Planning, University of Liverpool, Liverpool L69 3BX, UK 
and delay vital operations. Here we compare experiences on communicating information during crises on volcanoes reawakening after long repose (El Hierro in the Canary Islands) and in frequent eruption (Etna and Stromboli in Sicily). The results provide a basis for enhancing communication protocols during volcanic emergencies.

\section{Keywords}

Communication - Volcano - Emergencies - Canary islands - Etna • Stromboli

\section{Introduction}

Volcanic crises are complex to manage, owing to uncertainty in the behaviour of volcanoes and of the people and organisations responding to an emergency. Complexity is especially acute at volcanoes showing unrest after long intervals of repose, from several decades to centuries. In such cases, the infrequency of eruptions, and consequent lack of data on the volcanic system, introduces a high level of uncertainty in forecasts of eruptions and their hazards. In addition, few if any of the responding authorities - from monitoring scientists to civil protection agencies and governmental bodies-may have had direct experience of volcanic behaviour. As a result, prepared response plans are either non-existent or tend to be based on generic procedures designed to cover the legal requirements established by the host country for such contingencies. The different authorities may also have been brought together for the first time to address an emergency. In combination, inexperience in the scientific and managerial aspects of a crisis, the absence of a specific response plan and the lack of previous interaction between scientists and emergency managers (and even between scientists of different disciplines) can produce levels of tension among personnel that impair communications between key responders and the quality and timing of the decisions being made (Fiske 1984; Voight 1988a, 1990; Aspinall et al. 2002; Solana and Spiller 2007; Solana et al. 2008; Barclay et al. 2008; McGuire et al. 2009).
The notion to establish professional guidelines for responding to volcanic emergencies has been discussed since at least the 1970s (Tazieff 1977; Bostok 1978; Sigvaldason 1978; Barberi and Gasparini 1979; Fiske 1979; Tomblin 1979). Two decades later, the International Association of Volcanology and Chemistry of the Earth's Interior (IAVCEI) published a set of recommendations for the conduct of scientists during volcanic crises (IAVCEI et al. 1999). The recommendations emphasized that emergency responses are optimized by effective teamwork and the presentation by scientists to non-specialists of a unified and objective evaluation of volcanic unrest and its possible outcomes. Although appealing in theory, the recommendations are not binding and have been followed only erratically in practice. An example is the response to the 2011-1012 eruption of El Hierro, in the Canary Islands, which occurred after more than 200 years of repose. Following the El Hierro crisis, the Spanish Civil Protection agency identified the need to develop protocols to enable better communication of information between scientists and with emergency responders and local governmental agencies and argued that these should be integrated into regional emergency planning. This paper presents the experience gained during the crisis and describes how protocols have been designed and the factors that have hindered their development. It also highlights good practice and the importance of building on the experience gained from communicating information about eruptions at frequently active volcanoes, using emergencies from Etna and Stromboli. 


\section{Communications During a Volcanic Crisis}

Good communication plays a key role in managing a volcanic emergency effectively (Peterson 1988; Tilling 1989; Solana and Spiller 2007; Solana et al. 2008; McGuire et al. 2009; Doyle et al. 2011). Three common obstacles to good communication are: (1) differences in the organisational cultures with which responders are familiar (2) uncertainty in forecasting volcanic behaviour, and (3) inexperience of addressing volcanic unrest. The potential of these factors to diminish efficient communication is rarely appreciated before an emergency begins and this, in turn, favours poor decisions being made under the conditions of high stress during volcanic unrest (McGuire et al. 2009).

\subsection{Organisational Cultures}

Emergency responses normally require collaboration between academic scientists and the civil authorities. These two groups work in institutions with contrasting organisational cultures. As identified by Handy (1978), academics, scientists and researchers have primarily individualistic personalities. Their association in groups (e.g., universities, research centres or teams) is commonly for personal convenience and to facilitate the advance of individuals in their field of study. Academics do not "willingly take orders [...] or compromise on their own plans" (Handy 1978, p. 39) and are rarely forced to do so by their organisations (Handy 1978). As a result, academic decisions on, for example, the amount and type of information to be communicated during an emergency, normally have to be agreed on an individual basis. This process, although democratic, makes management and decision making through consensus very difficult and time consuming. It is not surprising, therefore, that the key recommendations of IAVCEI et al. (1999) - to value different expertises and approaches equally, to share information and logistical resources and to work as a team that speaks with a single voice and rewards self-sacrifice - are not always adopted by individuals during emergencies, especially those without previous experience of a volcanic crisis. This was illustrated by an informal survey in 2013 among participants of an international project on volcanic unrest in Europe and Latin-America (Fig. 1). The 21 interviewees represented 12 countries and scientists with different levels of seniority, 15 of which had experience responding or being involved directly or indirectly in 3 or more volcanic crisis. Of these 21 experts, 13 recognised personal ego and individual interests as the main barriers to communications between scientists during volcanic emergencies (Fig. 1).

The individualistic attitudes of many academic scientists contrast sharply with the culture of the civil authorities who are in charge of a crisis. Emergency managers are typically civil servants who work in a hierarchy designed to help their organisation achieve its goals. Individual ideas are rarely expressed except as part of agreed policy (Handy 1978). Managers are thus used to responding to information that has already been agreed by expert advisers and are usually reluctant to engage in evaluating diverging opinions or uncertainty in forecasts of a volcano's behaviour (Solana et al. 2008). Academic debate may therefore be perceived as indecision among experts and so raise questions about the quality of scientific advice being received. As a result, essential information from the advising scientists may not be communicated effectively to the emergency managers.

\subsection{Uncertainty}

Expressions of uncertainty may be perceived as indecision and so hinder the communication of scientific information. A common example is the delivery of eruption forecasts. Forecasts contain numerous sources of uncertainty because of the natural variations in the behaviour of magmatic 


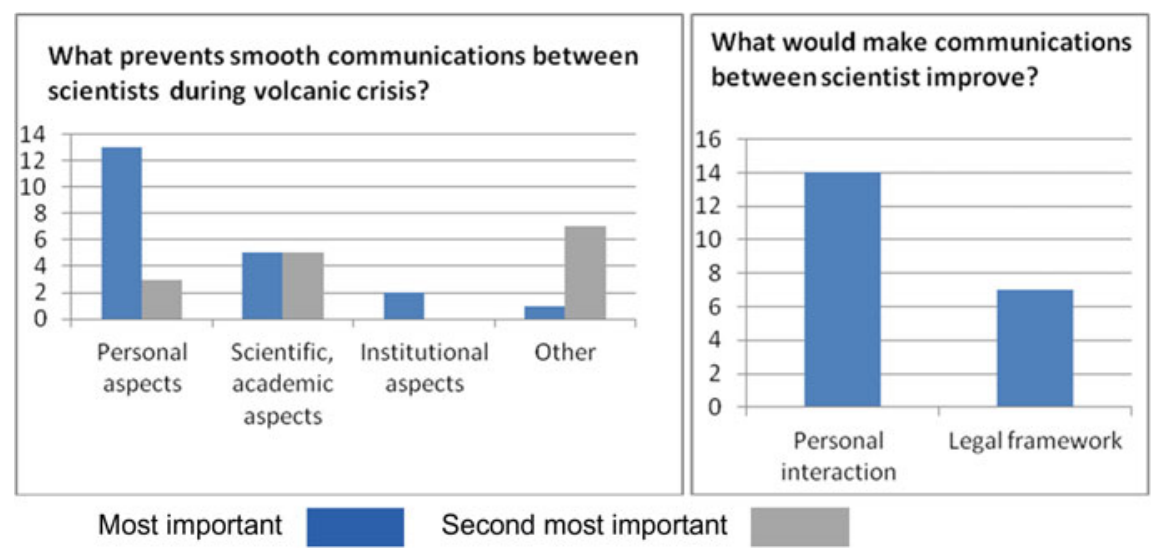

Fig. 1 Results from an informal survey of 21 volcanologists during the "Scientific advice, decision-making and risk communication" Vuelco meeting in 2013 (Solana and Fearnley 2013). Left, "Personal aspects" include personality, ego, personal interest, visibility, status. "Scientific/academic aspects" include ownership of data, publishing pressure, career progression. "Institutional aspects" include legal frameworks of institutions,

systems Marzocchi et al. (2012) and incomplete understanding of a specific volcano (e.g. Doyle et al. 2014) or incomplete data sets from research monitoring networks, especially emergency networks installed after the first signs of unrest. Even when appropriate monitoring is in place, uncertainty remains as to whether unrest will lead to an eruption or intrusion, because both are associated with similar changes in precursory signal (Tilling 1989). Such uncertainty is compounded when monitoring data are contradictory (e.g., increases in geochemical indicators which do not correlate with seismic or deformation data) and can lead to critical delays in forecasting and decision making with fatal consequences, as seen in Mt. Ontake in Japan, where a sudden eruption in September 27, 2014 surprised scientists monitoring the volcano and killed 23 people (Oskin 2014). Eruptions may also occur without detected precursory unrest, such as the so-called "silent" 2004 eruption at Mount Etna in Sicily (Burton et al. 2005) and the "passive" eruptions described for Kilauea in Hawaii (Bell and Kilburn 2011).

To aid the communication of uncertainty, several methodologies have been developed for evaluating the probabilities of an eruption, institutional status and agreed responsibilities. "Others" include lack of experience, uncertainty, culture, discipline rivalry. Right, Aspects of personal interaction include frequent face to face contact, joint experience in crisis, moderator/expert elicitation methods, grouping all teams together. Legal framework aspects include legalised protocols or rules, pre-agreements for data sharing

including Bayesian statistics and expert elicitation (e.g. Newhall and Hoblitt 2002; Aspinall et al. 2003; Marti et al. 2008; Marzocchi et al. 2008; Marzocchi and Bebbington 2012; Sobradelo et al. 2015), as well as the incorporation of deterministic models (Voight 1988b; Kilburn and Voight 1998; De La Cruz-Reyna and Reyes-Davila 2001; Kilburn 2003, 2012). On their own, however, probabilities are open to different interpretations by scientists and civil authorities and agreement on its meaning might not be reached.

As discussed by Doyle et al. (2011), communicating information does not necessarily have to imply that a consensus has been reached or that uncertainty is lacking, but it is imperative that all such issues are conveyed using appropriate language and with an understanding of the scientific culture of groups involved in advising decision makers. Thus, the civil authorities can favour methods other than probabilities for receiving forecasts (Solana et al. 2008), such as preferred time windows (Swanson et al. 1983), precursory scenarios and comparison with uncertainties associated with events that are locally more familiar. Overall, information will 
generally be more effectively communicated when presented in a form preferred by the recipient rather than imposed by the sender.

\subsection{Inexperience}

Lack of experience compounds poor communication due to different organisational cultures and the presentation of scientific information. Experience is gained not only through repeated exposure to volcanic unrest, but also by learning from mistakes. Admitting that mistakes have been made tends to be associated with failure and so not to be recorded. Notable exceptions reflecting on the management of volcanic crisis are Voight (1988a, 1990) on Nevado del Ruiz, Fiske (1984) on St. Vincent and Guadeloupe or Aspinall et al. (2002) in Montserrat. Reluctant recording is especially damaging to responses at volcanoes reawakening after long repose where the inherent uncertainty on the behaviour of volcanic system is highest. By virtue of the long repose intervals, few teams or individuals have the opportunity to respond more than once to such an emergency during their professional careers. The benefit of experience strongly depends, therefore, on published accounts of previous events. When accounts focus only on the successful aspects of a response, a false impression may be conveyed that mistakes are rare; and teams may also minimise the role played by good fortune rather than clear judgement Newhall and Punongbayan (1996). As a result, inexperienced teams may undervalue the potential difficulties in responding to an emergency and so unnecessarily repeat mistakes from the past. Global circumstances today are particularly acute, given the gap of nearly 25 years since the last large, VEI 6 eruption (Pinatubo in 1991) and more than 30 years has elapsed since the last volcanic disaster involving tens of thousands of deaths Chester et al. (2000) i.e. the 1984 eruption of Nevado del Ruiz in Colombia (Voight 1990). Based on statistics from the past 200 years (Siebert et al. 2010), at least half the volcanoes in eruption during the next century are expected to reawaken after a repose interval of 100 years or more. The scientists and officials responsible for managing an emergency will have no experience of the particular volcano's behaviour and, possibly, little or no direct experience of responding to volcanic eruptions in general.

The 2011-2012 unrest and eruption of El Hierro illustrates how communication during an emergency can be hampered by inexperience, organisational culture and forecasting uncertainty Marrero et al. (2015), Carracedo et al. (2015). This example is compared below with methods that have been developed at Italy's frequently-erupting volcanoes Etna and Stromboli. Together, the case studies indicate best-practice methods for maintaining good communications when responding to volcanic unrest.

\section{Case Studies}

\subsection{Communications During the 2011-2012 Eruption of El Hierro, Canary Islands}

Since the 1990s, the Canary Islands have been recognised as a high-risk volcanic area by the international scientific community. In particular, Mt Teide on Tenerife was selected as a UN-IDNDR decade volcano as well as a EU laboratory volcano. Nevertheless, the long return period of eruptions has encouraged a low perception of volcanic risk among national and local authorities and, hence, a reactive attitude to planning for volcanic emergencies is also evident. An indication of the low priority given to the threat of volcanic activity has been the government's under-investment in a multidisciplinary monitoring system for volcanic activity (Marti et al. 2009). For example, despite a general scientific call for an appropriate monitoring network during the 2004 seismo-volcanic crisis on Tenerife (Salomone 2004), little was invested until the 2011 unrest at El Hierro, when a comprehensive geophysical network was deployed there (López et al. 2012). Initiatives to rationalise and coordinate volcanic research in the region have also lacked economic support. For example, the creation of a comprehensive Volcanological Institute on the Canaries was demanded by the 
Spanish Senate in 2005, the Parliament of the Canaries in 2006 and the Spanish Congress in 2009; even so, the only initiative to produce an open and inclusive research group on the islands received only limited funding from the local council in Tenerife and had instead to be created as a commercial entity.

The lack of preparedness was highlighted in 2011, when El Hierro, the westernmost and youngest island in the Canaries, entered eruption in October for the first time in recorded history. It was also the first eruption in the Canaries in 40 years. After four months of low magnitude seismic activity frequently felt by the population, together with enhanced diffuse emissions of $\mathrm{CO}_{2}$ and $\mathrm{H}_{2} \mathrm{~S}$ (Pérez et al. 2012) and continuous surface and ground deformation which reached a maximum of $5 \mathrm{~cm}$ (López et al. 2012), an eruption was confirmed off the island's southern coast (Fig. 2). Being submarine, the eruption did not cause personal or material damage, but had an important impact on the small local businesses as well as causing anxiety and insecurity to some of the local population, as is clear on the concerns voiced in the media and directly through the digital version of the local newspaper, Diario del Hierro (www.diarioelhierro.com).

The legal context of the Canary Islands is important in framing some of the scientific issues that arose during the crisis. Although constitutional relationships between metropolitan Spain and the Canaries (and Spanish law more generally) are complex and beyond the scope of the present paper, a general statement of the key issues is presented next. The Canary Islands are a region of Spain with a special political status which allows them a level of self-determination and government in many areas of policy. The Civil Protection is one of the organisations with relative independence and can plan for and manage local and regional emergencies, though within an overall framework of laws approved by the central Spanish Government. Despite legislation requesting a specific plan for volcanic emergencies in Canaries since 1996, the first protocol to respond to an emergency was created as a response to the seismo-volcanic crisis of 2004 in Tenerife (Salomone 2004; PEVOLCA 2010).

Within this legal framework, in 2008 the Canarian Civil Protection produced a plan for volcanic emergencies known as PEVOLCA, Plan de Emergencias Volcanicas de Canarias (Volcanic Emergencies Plan for the Canaries). The plan was approved in 2010 and established which groups would form the scientific advisory committee and their roles and responsibilities. The original 2004 protocol recommended that the scientific committee be comprised of representatives from most of the local and national scientific institutions involved in volcanic research and monitoring in the Canaries. However, the 2010 PEVOLCA plan instead established a scientific advisory committee consisting of the National Geographical Institute (IGN), the
Fig. 2 The island of El Hierro, its position within the Canary Islands (inset) and the location of the offshore 2011 eruption (star). The village of La Restinga (pop. 600) is marked with an open circle

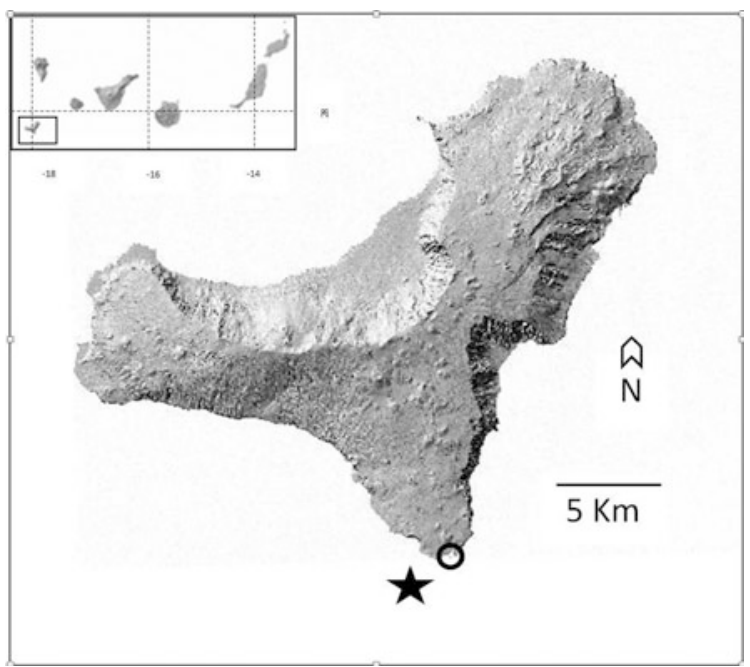


Spanish National Research Centre (CSIC), the National Meteorological Agency (AEMET) and the Civil Protection. This selection created much ill feeling amongst local scientific institutions, which could only participate in the scientific advisory committee meetings by invitation. It also had important implications for the local groups, which, in the absence of a formal role during the emergency, were left in a vulnerable legal position when their staff provided scientific advice and, without specific funding, were placed in financial difficulty when participating in committee meetings.

When the PEVOLCA plan was activated during the 2011-2012 El Hierro emergency, the Civil Protection invited all the principal volcanological research groups to the scientific advisory committee. It soon became apparent that the groups were not readily sharing all the available data, so the Civil Protection authority was eventually forced to act as a mediator. Independently-funded institutions and also groups funded through research projects argued that their data were not public and did not belong to the State. Ill feeling also developed because of the lack of access to resources, such as boats and helicopters for monitoring, and also data: for example, the establishment of an exclusion zone including the eruption site and its surroundings, meant that regular sampling was much easier for members of the Scientific Advisory Committee than it was for other groups. The six-month duration of the crisis also highlighted differences in funding between the formal monitoring group (IGN), that could rely on public funds for their continuous presence on the island and other monitoring groups, which struggled to meet their overheads.

In addition to the PEVOLCA scientists, researchers from other national and international research organisations temporarily joined in monitoring, sampling and research and some occasionally publicized their opinions in the local and national media. Although the majority of opinions were not especially controversial, some of the more speculative comments on the potential evolution of the crisis and the eruption, did create concern within the scientific groups who had followed the crisis from the beginning as well as some of the local population (see news comments at www.diarioelhierro.com).

\subsection{Lessons Learned on Communications During Recent Eruptions of Etna and Stromboli, Italy}

Frequently eruptions at a volcano favour the development of reliable monitoring and efficient communications among scientists, the Civil Protection and the public. Etna and Stromboli (Fig. 3a), for example, have permanent, multidisciplinary monitoring systems which enable precursory signals to be detected and recognised well in advance of an eruption (Bonaccorso et al. 2004; Patané et al. 2004; Puglisi et al. 2004; Martini et al. 2007; Bertolaso et al. 2008a, b; Rizzo et al. 2008; Tarchi et al. 2008; Calvari et al. 2010, 2011; Di Traglia et al. 2014). In addition, the responsibilities of the monitoring scientists have been clearly identified by the Italian Government and Civil Protection authorities. The latter funds monitoring networks and has frequent direct contact with the scientists in charge of coordinating the monitoring (Bertolaso et al. 2008b).

Legal responsibility for volcano and earthquake monitoring in Italy rests with the INGV (Istituto Nazionale di Geofisica e Vulcanologia). The Civil Protection (DPC, Dipartimento della Protezione Civile) funds not just the INGV, but also university teams that may duplicate or complement the data collected by the INGV. The university teams (called Centri di Competenza or Centres of Expertise) share data and ideas with the INGV and DPC during volcanic crises. Although the number of university personnel is much smaller than for the INGV (several tens compared with 800), the duplication of data from different teams allows alternative interpretations that encourages a more complete view of the phenomena being monitored. During the last fifteen years, implementation of this system has produced well-established and efficient management procedures for responding to crises at both Etna and Stromboli (Bertolaso et al. 2008b; 

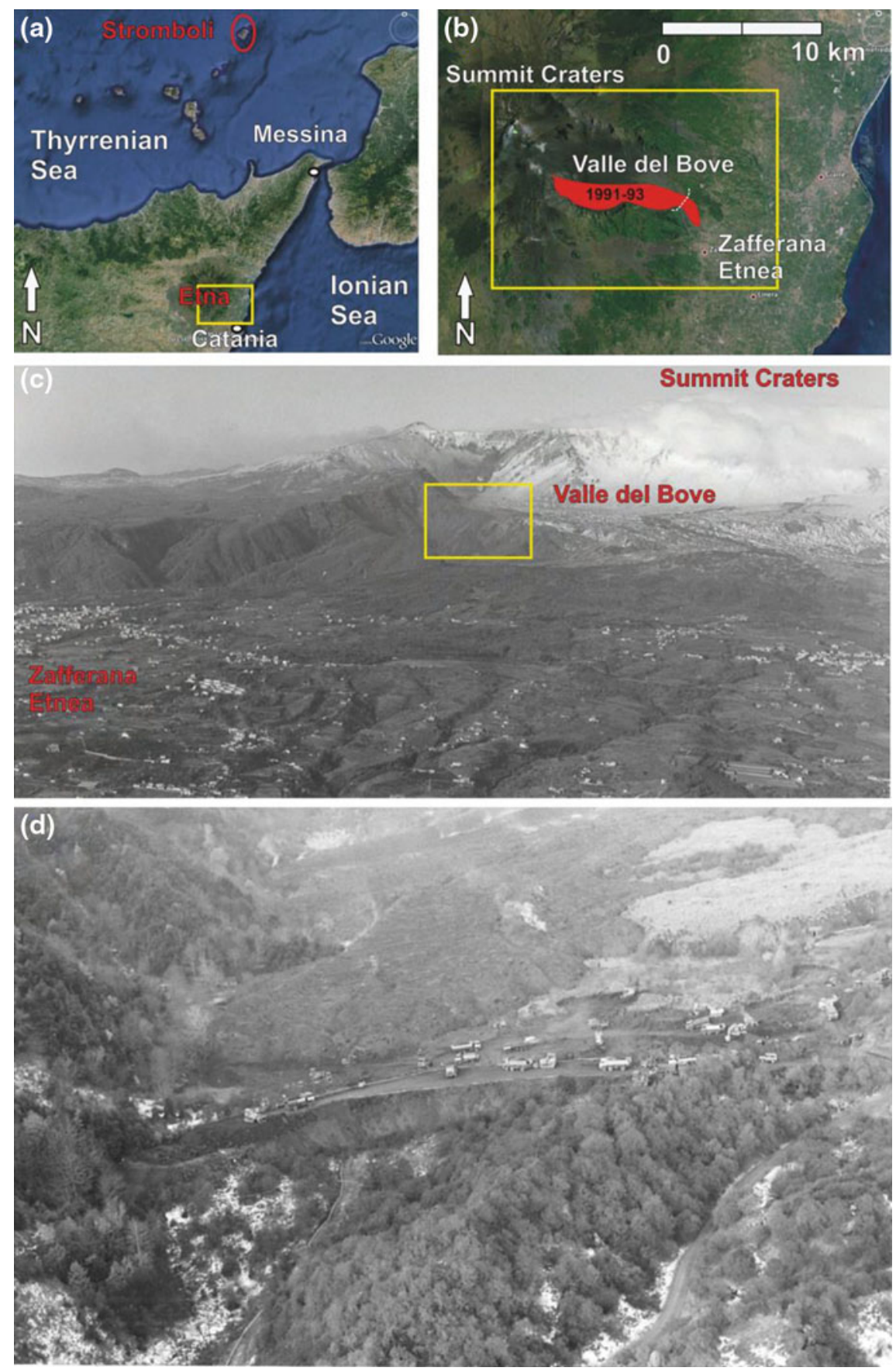

Fig. 3 a Google Map displaying southern Italy, with Stromboli volcano (red circle) at the NE end of the Aeolian Archipelago, and Etna volcano just $\mathrm{N}$ of Catania, on the East flank of Sicily. The yellow square displays the area magnified in $\mathbf{b}$. $\mathbf{b}$ Google map of the eastern flank of Etna volcano, comprising the summit craters, the Valle del Bove depression with the 1991-1993 lava flow field (in red), and the position of Zafferana Etnea town. The white dotted line at the end of the lava flow field shows the position of the earth dam built up in January 1992.
The yellow square displays the area magnified in c. c View from East of Etna's eastern flank displaying the Summit Craters, the Valle del Bove, and the position of Zafferana town. Photo by Alfio Amantia, taken from helicopter on 23 December 1991, a few days after the start of the eruption. The yellow square displays the area magnified in d. d Photo by Alfio Amantia, taken from helicopter on 5 January 1992, showing the earth dam built up at the exit of the Valle del Bove, with several trucks working on its top, and a large lava flow approaching to it 
Bonaccorso et al. 2015). Even under such favourable conditions, however, communications during a crisis can be very challenging when a population is directly threatened, as illustrated by the 1991-1993 eruption on Etna (Barberi and Villari 1994; Calvari et al. 1994) and the 20022003 activity on Stromboli (Calvari et al. 2005, 2006; Bertolaso et al. 2008a).

When the safety of people is involved, considerable pressure is placed on the scientists from both the population and government agencies, specifically to analyse data and provide information and forecasts quickly, which diminishes both productivity and efficiency. Data sharing and discussion of differing interpretations is of paramount importance, but the scientific community and Civil Protection must provide an agreed interpretation if they are to keep the trust of the population. The 1991-1993 flank eruption at Etna volcano (Fig. 3b) produced the largest compound lava flow field of the last three centuries, with $\sim 250$ million $\mathrm{m}^{3}$ of lava being emplaced along the southern margin of the barren Valle del Bove (VDB) on the eastern flank of the volcano (Calvari et al. 1994; Stevens et al. 1997). From there it approached the village of Zafferana Etnea (Fig. 3b, c), about $9 \mathrm{~km}$ from the eruptive fissure (Calvari et al. 1994). The eruption started on 14 December 1991 and, after an initial effusive phase during which the lava rapidly spread within the VDB, the Government decided to build an earthen barrier, $21 \mathrm{~m}$ high and $234 \mathrm{~m}$ long, across a narrow exit from the valley (Fig. 3b-d) in order to confine the lava and protect Zafferana Etnea (Barberi and Villari 1994). The barrier was completed on January 1st 1992 (Barberi and Villari 1994, Fig. 3d) and worked effectively for three months until April 7th 1992. However, the growth of lava tubes within the lava flow field significantly increased the potential of the lava to spread down slope (Calvari and Pinkerton 1998), and resulted in lava piling up behind and then spilling over the barrier to advance towards Zafferana Etnea (Calvari et al. 1994; Calvari and Pinkerton 1998).

At this stage, the people of Zafferana Etnea were seriously concerned for their safety, because they could observe the lava flows advancing towards their homes, less than $2 \mathrm{~km}$ away. Mistrust of the authorities spread among the population, especially when the first attempts to divert the lava (initially carried out at the lower end of the lava flow field) were unsuccessful. This was reinforced by the attention given by the local and national media to differing opinions expressed by scientists and Civil Protection officials over the best solutions to apply to divert the lava. Disagreements were amplified by the media, thus increasing suspicions, doubts and distrust (Barberi and Villari 1994). The population exerted pressure through their elected representatives to halt attempts for changing the course of the lava (e.g., with the use of bombs and destruction of forests) and public trust started to return only after daily meetings between scientists and the population were organised, with additional information being released by radio and television (Barberi et al. 1993; Barberi and Villari 1994; Barberi and Carapezza 2004). At the daily meetings the scientists explained "step by step" and justified what they were doing (Barberi and Villari 1994). Strangely, trust in and esteem for the scientists did not grow even when the safety of Zafferana Etnea was assured by the successful diversion of lava from a location closer to the eruptive fissure, because the attention of the media by then had already moved on to other, more dramatic topics (Barberi and Villari 1994), so highlighting the important role of the media in influencing public perception.

Ten years later, during a major flank eruption in 2002-2003, information to both the media and the population were communicated, not only by radio and television, but also through the internet, where maps, reports, photos and data were continually updated. The collaboration between scientists working for different institutions and universities (even from different countries) proved essential to understand and model eruptive processes, mitigate risks and obtain the best possible results (Bonaccorso et al. 2015). Following this eruption, a key priority was to produce prompt hazard assessment and develop expertise in the modelling of lava flows within the INGV. This was achieved through projects funded by the Italian Government and the DPC. 
Since then, communities on Etna have become involved in the monitoring effort by reporting information on any ash fall to the monitoring room of the INGV's Etna Observatory in Catania. They have also been invited to collaborate with ash sampling, thus allowing a unique and extensive sample collection of the several lava fountain episodes spreading ash over a large area $(\sim 30 \mathrm{~km}$ wide and over $200 \mathrm{~km}$ long) on and beyond the eastern flank of the volcano (Andronico et al. 2008). This collaboration has increased public understanding of eruptive events and served to increase trust in the work of scientists.

During Etna's 2002-2003 eruption, the INGV had simultaneously to face a volcanic crisis at Stromboli, the most active of the Aeolian Islands about $60 \mathrm{~km}$ to the north (Fig. 3a). The start of this eruption was marked by a tsunami that injured three people and caused damage along the coastal area of the island (Tinti et al. 2003). The tsunami was triggered by submarine and subaerial landslides (Bonaccorso et al. 2003) and was soon followed by the opening of an eruptive fissure with lava flowing down the north flank of the island to the sea for several months (Calvari et al. 2005). While lava was still pouring out from the fissure, the summit crater produced a very large explosion (Calvari et al. 2006; Bonaccorso et al. 2012) that damaged houses and buildings in nearby villages and triggered fires on vegetated slopes. The Civil Protection responded rapidly, building an observatory (COA, Centro Operativo Avanzato) where all the monitoring signals from the INGV and other universities were received (Bertolaso et al. 2008a). These monitoring networks were greatly expanded and improved using special financial support from the Civil Protection Authority. Daily meetings were organized between academic and INGV scientists and the Civil Protection to enable data comparison and sharing, and this resulted in a much deeper understanding of the volcanic activity (Calvari et al. 2008). The knowledge of the volcanic system was also greatly improved because of the funds and research projects initiated by the DPC (Bertolaso et al. 2008a). Since the monitoring of Stromboli was shared between INGV and other institutions, such as the Universities of Florence and Rome (Bertolaso et al. 2008a), the communication of scientific results to the population and the media was strictly controlled by the Civil Protection in order to avoid disseminating divergent or contrasting points of view.

When the eruption started, 400 inhabitants were informed of the possibility of tsunamis, and 330 spontaneously decided to leave the island. Access to the island was temporarily denied, except to monitoring scientists, volcanological guides, The Civil Protection and authorized journalists. Although implemented for safety reasons, the exclusion created ill feelings amongst a team of academic scientists not involved in monitoring, who were prevented access for sampling the erupted products. The Italian Civil Protection addressed this problem by sharing a number of samples between the monitoring and the academic teams. The population returned of their own accord two months later, and within three months from the start of the eruption the island was reopened to tourists.

Initially, a conflict between the local population and the media arose, caused by the fear that dramatic information on the activity of this volcano would scare away tourists and damage the local economy (Bertolaso et al. 2008a). To maintain a high level of awareness of volcanic hazards amongst the local population and to provide guidance on personal safety, the DPC has since annually published and distributed leaflets before the start of the tourist season. However, this basic information has not been welcomed by the whole of the local population, again because of concerns of reducing tourism.

\section{General Aspects of the Development of a Protocol for the Communication, Management and Use of Scientific Information During Volcanic Emergencies in Canaries}

The experience gained at Etna, Stromboli and El Hierro reinforce the findings from other volcanoes (e.g., Peterson 1988; Tilling 1989; Solana et al. 2008; McGuire et al. 2009; Doyle et al. 
2011) that clear procedures for the sharing, discussion and communication of scientific information are crucial for the effective management of volcanic emergencies, especially on volcanoes with long periods of repose, where uncertainty about the volcanic systems are greatest.

In the Canaries, the Civil Protection has proposed that a new Scientific Committee for the Assessment and Surveillance of Volcanic Phenomena (CSEV) be created as an inclusive committee for the study and analysis of seismo-volcanic risk. This committee will be coordinated by the Civil Protection and consist of representatives from each of the groups within the formal advisory committee of PEVOLCA, as well as from each of the local universities and research centres. External advisors may also be appointed at the discretion of the coordinator.

CSEV's aims and objectives are:

- to identify possible precursory phenomena to eruptions in the Canary Islands;

- to assess data obtained from monitoring networks and instruments;

- to produce forecasts of volcanic activity and the consequences for the Civil Protection Authorities;

- to establish a methodology for monitoring during volcanic eruptions, for evaluating data and for formulating hypotheses about the likelihood and potential impact of an eruption.

To avoid the difficulties encountered during the El Hierro crisis, CSEV has further established a series of regulations that must be satisfied for participation:

- the requirement to sign an agreement to obey the rules of the committee;

- the use of information and data must be shared by committee members exclusively to advise the Civil Protection (and not for personal or institutional gain);

- the selection of one representative from each group by democratic procedures;

- compulsory attendance at sessions of the committee;
- the need to produce and submit written reports two days before scheduled meetings with information on forecasts, eruption scenarios and their associated probabilities;

- following debate and discussion of data, the need to reach a consensus and produce a written document on the situation or, if a consensus is not reached, the basis for different interpretations should be clearly noted and explained;

- confidentiality and coordination in the dissemination of information about the results and of debates held within meetings.

\section{Discussion}

The challenges and successes presented in this paper emphasize the varied nature of communication problems that have been encountered in recent crises and the lessons that can be learned. A summary of selected information from these crises is presented in Table 1.

The eruption of El Hierro in 2011 provided the best possible scenario for an eruption from the management point of view. The eruption occurred offshore, meaning that no lives were seriously threatened or property damaged; it affected a sparsely populated area (El Hierro has a population of ca. 10,000 , the smallest in the Canary Islands) and hence involved an easily manageable number of people; and it displayed several weeks of increasing precursory activity which permitted emergency arrangements to be put in place. Moreover, a plan to manage volcanic crises was in place before the eruption and therefore, while the scientific management of the crisis presented challenges, the operational management of the crisis ran smoothly. Good fortune certainly helped the smooth operation and, had the 2011 eruption occurred inland, or with brief precursory signals, the consequences might have been more serious.

The difficulties in scientific management stemmed mainly from a non-inclusive policy established by the national government, lack of experience, differences in organisational cultures, 
Table 1 Summary of selected characteristics of the case studies, good practice actions and lessons learnt

\begin{tabular}{|c|c|c|c|c|}
\hline & El Hierro 2011-2012 & Etna 1991-1993 & Etna $2002-2003$ & $\begin{array}{l}\text { Stromboli 2002- } \\
2003\end{array}$ \\
\hline $\begin{array}{l}\text { Previous VE } \\
\text { plan }\end{array}$ & Yes & Yes & Yes & Yes \\
\hline $\begin{array}{l}\text { Previous } \\
\text { experience in } \\
\text { the volcanic } \\
\text { system }\end{array}$ & No & Yes & Yes & Yes \\
\hline $\begin{array}{l}\text { Understanding } \\
\text { of the volcanic } \\
\text { system }\end{array}$ & Low & High & High & High \\
\hline $\begin{array}{l}\text { Direct threat to } \\
\text { life/property }\end{array}$ & No & Yes & No & Yes \\
\hline $\begin{array}{l}\text { Previous } \\
\text { experience on } \\
\text { VE }\end{array}$ & Some (1 previous) & High & High & High \\
\hline \multirow[t]{4}{*}{$\begin{array}{l}\text { Good practice } \\
\text { key points }\end{array}$} & Rapid response to crisis & $\begin{array}{l}\text { Coordination of scientific } \\
\text { information to the public }\end{array}$ & $\begin{array}{l}\text { Inclusive and open } \\
\text { monitoring effort }\end{array}$ & $\begin{array}{l}\text { Inclusive and open } \\
\text { monitoring effort }\end{array}$ \\
\hline & $\begin{array}{l}\text { VE plan revised to } \\
\text { incorporate lessons learnt }\end{array}$ & $\begin{array}{l}\text { Post-eruptive needs } \\
\text { assessment }\end{array}$ & $\begin{array}{l}\text { Continuous information } \\
\text { to the public }\end{array}$ & $\begin{array}{l}\text { Regular (yearly) } \\
\text { information } \\
\text { campaign }\end{array}$ \\
\hline & $\begin{array}{l}\text { Ethical behaviour of most } \\
\text { scientists } \\
\text { directly/indirectly involved }\end{array}$ & Permits for researchers & $\begin{array}{l}\text { Involvement of the } \\
\text { public in monitoring }\end{array}$ & $\begin{array}{l}\text { Creation of an } \\
\text { in-site inclusive } \\
\text { observatory }\end{array}$ \\
\hline & & & $\begin{array}{l}\text { Civil protection } \\
\text { management of priority } \\
\text { research/monitoring } \\
\text { funds }\end{array}$ & $\begin{array}{l}\text { Recognition of the } \\
\text { roles of other } \\
\text { academic } \\
\text { researchers }\end{array}$ \\
\hline \multirow[t]{4}{*}{ Lessons learnt } & $\begin{array}{l}\text { More inclusivity in } \\
\text { scientific committee }\end{array}$ & $\begin{array}{l}\text { Regular communication } \\
\text { with the public }\end{array}$ & $\begin{array}{l}\text { Changeable nature of } \\
\text { volcanic threat }\end{array}$ & $\begin{array}{l}\text { Changeable nature } \\
\text { of volcanic threat }\end{array}$ \\
\hline & $\begin{array}{l}\text { Clearer procedures for } \\
\text { involvement of scientific } \\
\text { groups }\end{array}$ & $\begin{array}{l}\text { Management of scientific } \\
\text { disagreements }\end{array}$ & $\begin{array}{l}\text { Importance of } \\
\text { duplication in data } \\
\text { collection for scientific } \\
\text { discussion }\end{array}$ & $\begin{array}{l}\text { Sharing of } \\
\text { scientific data and } \\
\text { resources (e.g. } \\
\text { samples) }\end{array}$ \\
\hline & $\begin{array}{l}\text { Need of legal frame to } \\
\text { cover liability of } \\
\text { collaborating } \\
\text { institutions/individuals }\end{array}$ & $\begin{array}{l}\text { Improved communication } \\
\text { with the media and } \\
\text { management of media } \\
\text { reports }\end{array}$ & & \\
\hline & $\begin{array}{l}\text { Need of contingency } \\
\text { funding for independent } \\
\text { advisors/collaborations }\end{array}$ & & & \\
\hline
\end{tabular}

$V E$ Volcanic emergency

lack of formal procedures for the sharing of information and the under-funding of monitoring networks. As demonstrated by the success of analogous procedures at Etna and Stromboli, the CSEV model to produce for the Canary Islands a more inclusive scientific advisory group is a positive step towards establishing a more integrated and collaborative volcanological research community. For successful implementation, the model needs to accommodate four key features.

Financing aspects to ensure that participants are not excluded because of lack of funding, not only for data collection and hazard mitigation, but also for the logistics of attending pre- sin- and post- eruption meetings of the advisory committee. One promising option would be to adapt the 
Italian system of providing funds through the national Civil Protection. In the longer term, funding is required to establish permanent and multidisciplinary monitoring networks, including local monitoring centres responsible for specific volcanoes in the Canaries. The centres provide a focus for liaising in particular with local communities and the Civil Protection. It is of course much easier to justify the necessary resources at frequently-erupting volcanoes, such as Etna and Stromboli. However, having at least a contingency for the rapid establishment of a multidisciplinary inclusive institution will encourage the coordination and sharing of data and contribute to the feeling of cohesion and camaraderie amongst the groups involved.

Legal aspects to protect against liability exposure (Marrero et al. 2015). Aspinall and Sparks (2004) describe an example from the United Kingdom Office of Science and Technology, which includes a clause that "appears to indemnify individual members of such a [scientific advisory] Committee" when acting "honestly, reasonably, in good faith and without negligence", although they warn that the phrase "without negligence" is subjective and can be lead to further disputes (quotations from Aspinall and Sparks (2004) pp. 5-6).

Aspects of the format and storage of information, to ensure the effective sharing of data. Examples include:

a. Type of data that should be shared between scientific groups, such as real time data, fast data, general data-forecasts, and rock and gas samples.

b. The content of scientific reports. On some occasions data would have to be part- processed before being shared in order for non-specialists to understand and be able to use it.

c. The frequency of delivering information, to establish how often data are to be received from each group. These timings should be flexible and realistic. For instance, the requirement of the Spanish Civil Protection to receive written forecasts two days in advance of a meeting may be neither feasible nor helpful, especially if daily meetings are required (following the procedures established at Etna and Stromboli).

d. The format preferred by recipients for the communication of forecasts, eruption scenarios and mitigation procedures.

e. Policies on the storage of information to decide which agency should be responsible for compiling and storing scientific data, the form of storage (e.g., as an electronic database, or as a website with restricted access), and the length of storage before data are made available for general use.

Procedures for integrating researchers from outside official monitoring groups. Volcanic eruptions provide opportunities for advancing the understanding of volcanic processes and, as identified by IAVCEI et al. (1999), establishing official and legal mechanisms to allow external research groups access to field data can yield insights of potential value to mitigation efforts. It would also reduce the possibility of ill feelings caused by exclusion.

\section{Conclusions}

Our experience of emergencies at frequentlyerupting and long-dormant volcanoes, reinforce the conclusions by IAVCEI et al. (1999) that the management of crises is optimised by officially approving, before an emergency, clear, and legally binding rules and protocols for the communication of scientific information between responding groups. As well as detailing the type, content, amount, format, frequency, storage and use of the information, the protocols should consider aspects such as confidentiality, inclusiveness, ethics, financing and legal aspects such as the liability of scientific groups.

Another important recommendation is to identify a coordinating body outside the monitoring and scientific teams-such as the Civil Protection - to manage discussions, collate forecasts and scenarios and agree a consensus (or the basis for different interpretations) and to ensure that all involved feel that their views and 
contributions are respected. Recognising the different organisational cultures of the responding groups is vital for a better understanding of each party's needs and limitations and for optimising the design of communication strategies.

Finally, the Italian model demonstrates the benefits of establishing an on-site, inclusive and multidisciplinary institution to produce and coordinate scientific information and to encourage collaboration and camaraderie. It also illustrates the advantages of incorporating external researchers, of sharing resources and of engaging the public to improve the understanding of the volcano in unrest. The allocation of appropriate government funding and resources to all these activities is, of course, key to their success.

Acknowledgements We would like to thank the organisers and participants of the VUELCO meeting in Rome in 2013 for their participation in an informal survey and especially Carina Fearnley for her help with the data collection. We also thank the scientific and civil defence personnel involved in the response to the 2011-2012 El Hierro emergency for sharing their opinions and concerns. A special thank you goes to Roger Jennings for highlighting the institutional and managerial differences between private and public organisations and academia. Finally we would like to thank the anonymous reviewers for their comments and advice.

\section{References}

Andronico D, Scollo S, Caruso S, Cristaldi A (2008) The 2002-03 etna explosive activity: tephra dispersal and features of the deposits. J Geophys Res 113:B04209. doi:10.1029/2007JB005126

Aspinall WP, Loughlin SC et al (2002) The Montserrat Volcano observatory; its evolution, organization, role and activities In: Druitt TH, Kokelaar BP (eds) The eruption of Soufriere Hills Volcano, Montserrat from 1995 to 1999; The Geological Society London Memoirs, vol 21, pp 71-91

Aspinall WP, Sparks RSJ (2004) Volcanology and the law. IAVCEI News 1:4-5, 11-12

Aspinall WP, Woo G, Voight B, Baxter PJ (2003) Evidence-based volcanology: application to eruption crisis. J Volcanol Geoth Res 128:273-285

Barberi F, Carapezza ML (2004) The control of lava flows at Mt. Etna. In: Bonaccorso A, Calvari S, Coltelli M, Del Negro C, Falsaperla S (eds) Mt. Etna: volcano laboratory, AGU Geophys Monogr 143:343-369. doi:10.1029/143GM21
Barberi F, Gasparini P (1979) A deontological code for volcanologists? (Letter to the editor). J Volcanol Geotherm Res 6:1-2

Barberi F, Villari L (1994) Volcano Monitoring and civil protection problems during the 1991-1993 Etna eruption. Acta Vulcanol 4:157-165

Barberi F, Carapezza ML, Valenza M, Villari L (1993) The control of lava flow during the 1991-1992. J Volcanol Geotherm Res 56:1-34

Barclay J, Haynes K, Mitchell T, Solana C, Teeuw R, Darnell A, Crosweller HS, Cole P, Pyle D, Lowe CJ, Fearnley C, Kelman I (2008) Framing volcanic risk communication within disaster risk reduction: finding ways for the social and physical sciences to work together. Communicating environmental geoscience. Geol Soc Lond Spec Publ 305:163-177

Bell AF, Kilburn CRJ (2011) Precursors to dyke-fed eruptions at basaltic volcanoes: insights from patterns of volcano-tectonic seismicity at Kilauea volcano, Hawaii. Bull Volcanol 74:325-339

Bertolaso G, De Bernardinis B, Cardaci C, Scalzo A, Rosi M (2008a) Stromboli (2002-2003) crisis management and risk mitigation actions. In: Calvari S, Inguaggiato S, Puglisi G, Ripepe M, Rosi M (eds) The Stromboli volcano, an integrated study of the 20022003 eruption. AGU Geophys Monogr 182:373-385. doi:10.1029/143GM30

Bertolaso G, Bonaccorso A, Boschi E (2008b) Scientific community and civil protection synergy during the Stromboli 2002-2003 Eruption. In: Calvari S, Inguaggiato S, Puglisi G, Ripepe M, Rosi M (eds) The Stromboli volcano, an integrated study of the 20022003 eruption. AGU Geophys Monogr 182:387-397. doi:10.1029/143GM31

Bonaccorso A, Calvari S, Garfì G, Lodato L, Patané D (2003) December 2002 flank failure and tsunami at Stromboli volcano inferred by volcanological and geophysical observations. Geophys Res Lett 30 (18):1941-1944. doi:10.1029/2003GL017702

Bonaccorso A, Campisi O, Falzone G, Gambino S (2004) Continuous tilt monitoring: lesson learned from 20 years experience at Mt. Etna. In: Bonaccorso A, Calvari S, Coltelli M, Del Negro C, Falsaperla S (eds) Mt. Etna: volcano laboratory. AGU Geophys Monogr 143:307-320. doi:10.1029/143GM19

Bonaccorso A, Calvari S, Linde A, Sacks S, Boschi E (2012) Dynamics of the shallow plumbing system investigated from borehole strainmeters and cameras during the 15 March 2007 Vulcanian paroxysm at Stromboli volcano. Earth Planet Sci Lett 357358:249-256. doi:10.1016/j.eps1.2012.09.009

Bonaccorso A, Calvari S, Boschi E (2015) Hazard mitigation and crisis management during major flank eruptions at Etna volcano: reporting on real experience. In: Detecting, modelling and responding to effusive eruptions. Geological Society London Special Publications, in print

Bostok D (1978) A deontological code for volcanologists? (Editorial). J Volcanol Geotherm Res 4:1 
Burton M, Neri M, Andronico D, Branca S, Caltabiano T, Calvari S, Corsaro RA, Del Carlo P, Lanzafame G, Lodato L, Miraglia L, Muré F, Salerno G, Spampinato L (2005) Etna 2004-05: an archetype for geodynamically-controlled effusive eruptions. Geophys Res Lett 32:L09303. doi:10.1029/2005GL022527

Calvari S, Pinkerton H. (1998). Formation of lava tubes and extensive flow field during the 1991-93 eruption of Mount Etna. J Geophys Res: Solid Earth 103(B11):27291-27301

Calvari S, Coltelli M, Neri M, Pompilio M, Scribano V (1994) The 1991-93 Etna eruption: chronology and lava flow field evolution. Acta Vulcanol 4:1-14

Calvari S, Spampinato L, Lodato L, Harris AJL, Patrick MR, Dehn J, Burton MR, Andronico D (2005) Chronology and complex volcanic processes during the 2002-2003 flank eruption at Stromboli volcano (Italy) reconstructed from direct observations and surveys with a handheld thermal camera. J Geophys Res 110:B02201. doi:10.1029/2004JB003129

Calvari S, Spampinato L, Lodato L (2006) The 5 April 2003 vulcanian paroxysmal explosion at Stromboli volcano (Italy) from field observations and thermal data. J Volcanol Geotherm Res. 149:160-175 doi:10. 1016/j.jvolgeores.2005.06.006

Calvari S, Inguaggiato S, Puglisi G, Ripepe M, Rosi M (eds) (2008) The Stromboli volcano, an integrated study of the 2002-2003 eruption. AGU Geophys Monogr 182:390 pp

Calvari S, Lodato L, Steffke A, Cristaldi A, Harris AJL, Spampinato L, Boschi E (2010) The 2007 Stromboli flank eruption: chronology of the events, and effusion rate measurements from thermal images and satellite data. J Geophys Res Solid Earth 115(B4):B04201. doi:10.1029/2009JB006478

Calvari S, Salerno GG, Spampinato L, Gouhier M, La Spina A, Pecora E, Harris AJL, Labazuy P, Biale E, Boschi E (2011) An unloading foam model to constrain Etna's 11-13 January 2011 lava fountaining episode. J Geophys Res 116:B11207. doi:10.1029/ 2011JB008407

Carracedo JC, Troll VR, Zaczek K, Rodríguez-González A, Soler V, Deegan FM (2015) The 2011-2012 submarine eruption off El Hierro, Canary Islands: New lessons in oceanic island growth and volcanic crisis management, Earth-Science Reviews, vol 150, November 2015, pp. 168-200

Chester DK, Degg M, Duncan AM, Guest JE (2000) The increasing exposure of cities to the effects of volcanic eruptions: a global survey. Environ Hazard 2:89-103

De La Cruz-Reyna S, Reyes-Davila GA (2001) A model to describe precursory material-failure phenomena: applications to short-term forecasting at Colima volcano, Mexico. Bull Volcanol 63:297-308

Di Traglia F, Nolesini T, Intrieri E, Mugnai F, Leva D, Rosi M, Casagli N (2014) Review of ten years of volcano deformations recorded by the ground-based InSAR monitoring system at Stromboli volcano: a tool to mitigate volcano flank dynamics and intense volcanic activity. Earth Sci Rev, in print
Doyle EH, Johnston DM, McClure J, Paton D (2011) The communication of uncertain scientific advice during natural hazards events. N Z J Psych 40(4):39-50

Doyle EH, McClure J, Johnston DM, Paton D (2014) Communicating likelihoods and probabilities in forecasts of volcanic eruptions. J Volcanol Geotherm Res 272:1-15

Fiske RS (1979) A deontological code for volcanologists? (Reply to editorial). J Volcanol Geotherm Res 5:211-212

Fiske RS (1984) Volcanologists, journalists, and the concerned local public: a tale of two crises in the Eastern Caribbean. In: Geophysics Study Committee (ed) Explosive volcanism: interception, evolution and hazard. National Academy Press, Washington, DC, pp 170-176

Handy C (1978) Gods of management, who they are, how they work and why they will fail. Pan LTD ed., $320 \mathrm{pp}$

IAVCEI, Subcommittee for Crisis Protocols, Newhall C, Aramaki S, Barberi F, Blong R, Calvache M, Cheminee JL, Punongbayan R, Siebe C, Simkin T, Sparks RSJ, Tjetjep W (1999) Professional conduct of scientists during volcanic crises. Bull Volcanol 60:323-334

IGN (s.n.) Vigilancia Volcanica. http://www.ign.es/ign/ layoutIn/volcaListadoEstaciones.do?codT=IGN\&desT= Estaciones\%20s\%EDsmicas\%20IGN. Accessed Jan 2015

Kilburn CRJ (2003) Multiscale fracturing as a key to forecasting volcanic eruptions. J Volcanol Geotherm Res 125:271-289

Kilburn CRJ (2012) Precursory deformation and fracture before brittle rock failure and potential application to volcanic unrest. J Geophys Res. doi:10.1029/ 2011JB008703

Kilburn CRJ, Voight B (1998) Slow rock fracture as eruption precursor at Soufriere Hills volcano, Montserrat. Geophys Res Lett 25:3665-3668

López C, Blanco MJ, Abella R, Brenes B et al (2012) Monitoring the volcanic unrest of El Hierro (Canary Islands) before the onset of the 2011-2012 submarine eruption. Geophys Res Lett doi:10.1029/ 2012GL051846

Marrero JM, Garcia A, Linares A, Berrocoso M, Ortiz R. (2015) Legal framework and scientific responsibilities during volcanic crises: the case of the El Hierro eruption (2011-2014) J Appl Volcanol 4:13. doi:10. 1186/s13617-015-0028-8

Marti J, Aspinall WR, Sobradelo R, Felpeto A, Geyer A, Ortiz R, Baxter P, Cole PD, Pacheco J, Blanco MJ, Lopez C (2008) A long-term volcanic hazard event tree for Teide-Pico Viejo stratovolcanoes (Tenerife, Canary Islands). J Volcanol Geotherm Res 178:543552. doi:10.1016/j.jvolgeores.2008.09.023

Marti J, Ortiz J, Gottsmann J, Garcia A, la Cruz-Reyna De (2009) Chracterising unrest during the reawakening of the central volcanic complex on Tenerife, Canary Islands, 2004-2005, and implications for assessing hazards and risk mitigation. J Volcanol Geotherm Res 182(1):23-33 
Martini M, Guidicepetro F, DAuria L, Esposito AM, Caputo T, Curciotti R, De Cesare W, Orazi M, Scarpato G, Caputo A (2007) Seismological monitoring of the February 2007 effusive eruption of the Stromboli volcano. Ann Geophys 50(6):775-788

Marzocchi W, Bebbington MS (2012) Probabilistic eruption forecast at short and long time scales. Bull Volcanol 74(8):1777-1805

Marzocchi W, Sandri L, Selva J (2008) BET_EF: a probabilistic tool for long- and short-term eruption forecasting. Bull Volcanol 70(5):623-632

Marzocchi W, Newhall C, Woo G (2012) The scientific management of volcanic crises. J Volcanol Geotherm Res 247-248:181-189

McGuire WJ, Solana MC, Kilburn CRJ, Sanderson D (2009) Improving communication during volcanic crises on small, vulnerable, islands. J Volcanol Geotherm Res 183:63-75

Newhall CG, Punongbayan RS (1996) The narrow margin of successful volcanic-risk mitigation. In: Scarpa R, Tilling RI (eds) Monitoring and mitigation of volcano hazards, pp 807-838

Newhall C, Hoblitt R (2002) Constructing event trees for volcanic crises. Bull Volcanol 64:3-20. doi:10.1007/ s00445010017364: 3. doi:10.1007/s004450100173

Oskin B (2014) http://www.scientificamerican.com/ article/how-a-deadly-volcano-erupted-in-japan-withoutwarning/. Accessed 20 Nov 2014

Patané D, Cocina O, Falsaperla S, Privitera E, Spampinato S (2004) Mt. Etna Volcano: a seismological framework. In: Bonaccorso A, Calvari S, Coltelli M, Del Negro C, Falsaperla S (eds) Mt. Etna: Volcano laboratory. AGU Geophys Monogr 143:147-165. doi:10.1029/143GM10

Pérez NM, Padilla GD, Padrón E, Hernández PA et al (2012) Precursory diffuse $\mathrm{CO}_{2}$ and $\mathrm{H}_{2} \mathrm{~S}$ emission signatures of the 2011-2012 El Hierro submarine eruption. Canary I Geophys Res Lett. doi:10.1029/ 2012GL052410

Peterson DW (1988) Volcanic hazards and public response. J Geophys Res 93:4161-4170

PEVOLCA (2010) Plan Especial de Protección Civil y Atención de Emergencias por riesgo volcánico en la Comunidad Autónoma de Canarias. Boletin Oficial de Canarias 140 (19/07/2010)

Puglisi G, Briole P, Bonforte A (2004) Twelve years of ground deformation studies on Mt. Etna Volcano based on GPS surveys. In: Bonaccorso A, Calvari S, Coltelli M, Del Negro C, Falsaperla S (eds) Mt. Etna: Volcano laboratory. AGU Geophys Monogr 143: 321-341. doi:10.1029/143GM20

Rizzo A, Aiuppa A, Capasso G, Grassa F, Inguaggiato S, Longo M, Carapezza ML (2008) The 5 April 2003 Paroxysm at Stromboli, a review of geochemical observations. In: Calvari S, Inguaggiato S, Puglisi G, Ripepe M, Rosi M (eds) The Stromboli Volcano, an integrated study of the 2002-2003 eruption. AGU Geophys Monogr 182:347-358. doi:10.1029/ $143 \mathrm{GM} 28$

Salomone M (2004) Crisis Volcanica en Tenerife. El Pais, 22 Nov 2004. http://elpais.com/diario/2004/11/22/ ultima/1101078001_850215.html. Accessed Jan 2015

Siebert L, Simkin T, Kimberley P (2010). Volcanoes of the world, 3rd edn. Smithsonian Institution \& University of California Press, $550 \mathrm{pp}$

Sigvaldason GE (1978) A deontological code for volcanologists? (Reply to editorial). J Volcanol Geotherm Res 4:I-III

Sobradelo R, Marti J, Kilburn C, Lopez C (2015) Probabilistic approach to decision-making under uncertainty during volcanic crises: retrospective application to El Hierro (Span) 2011 volcanic crisis. Nat Hazards 76(2):979-998

Solana C, Spiller C (2007) Communication between professionals during volcanic emergencies. Eos Trans AGU 88(28)

Solana MC, Kilburn CRJ, Rolandi G (2008) Communicating eruption and hazard forecasts on Vesuvius, Southern Italy. J Volcanol Geotherm Res 172: 308-314

Stevens NF, Murray JB, Wadge G (1997) The volume and shape of the 1991-1993 lava flow field at Mount Etna. Sicily Bull Volcanol 58(6):449-454

Swanson DA, Casadevall TJ, Dzurisin D, Malone SD, Newhall CG, Weaver CS (1983) Predicting eruptions at Mount St. Helens, June 1980 through December 1982. Science 221(4618):1369-1376

Tarchi D, Casagli N, Fortuny-Guasch J, Guerri L, Antonello G, Leva D (2008) Ground deformation from ground-based SAR interferometry. In: Calvari S, Inguaggiato S, Puglisi G, Ripepe M, Rosi M (eds) The Stromboli Volcano, an integrated study of the 20022003 eruption. AGU Geophys Monogr 182:359-372. doi:10.1029/143GM29

Tazieff H (1977) La Soufrière, volcanology and forecasting. Nature 269:96-97

Tilling RI (1989) Volcanic hazards and their mitigation: progress and problems. Rev Geophys 27:237-269

Tinti S, Pagnoni G, Zaniboni F (2003) Tsunami generation in Stromboli island and impact on the north-east Tyrrhenian coast. Nat Hazards Earth Syst Sci 3:299309

Tomblin J (1979) A deontological code for volcanologists? (Reply to Editorial). J Volcanol Geotherm Res 5:213-215

Voight B (1988a) Countdown to catastrophe. Earth Miner Sci $57: 17-30$

Voight B (1988b) A method for prediction of volcanic eruptions. Nature 332:125-130

Voight B (1990) The 1985 Nevado del Ruiz volcano catastrophe: anatomy and retrospection. J Volcanol Geotherm Res 44(3-4):349-386 
Open Access This chapter is licensed under the terms of the Creative Commons Attribution 4.0 International License (http://creativecommons.org/licenses/by/4.0/), which permits use, sharing, adaptation, distribution and reproduction in any medium or format, as long as you give appropriate credit to the original author(s) and the source, provide a link to the Creative Commons license and indicate if changes were made.
The images or other third party material in this chapter are included in the chapter's Creative Commons license, unless indicated otherwise in a credit line to the material. If material is not included in the chapter's Creative Commons license and your intended use is not permitted by statutory regulation or exceeds the permitted use, you will need to obtain permission directly from the copyright holder. 